\title{
Radiotherapy for a Phalanx Bone Metastasis of a Lung Adenocarcinoma
}

\author{
Shakeel Sumodhee ${ }^{\mathrm{a}} \quad$ Eric Huchot ${ }^{\mathrm{b}} \quad$ Gaelle Peret $^{\mathrm{b}} \quad$ Christian Marchal $^{\mathrm{a}}$ \\ Fabrice Paganin ${ }^{b}$ Valerie Magnin ${ }^{a}$ \\ Departments of ${ }^{a}$ Radiation Oncology and ${ }^{b}$ Pneumology, CHU Sud Réunion, Saint-Pierre, \\ Réunion, France
}

\section{Key Words}

Acrometastasis · Phalanx $\cdot$ Lung adenocarcinoma $\cdot$ Radiotherapy $\cdot$ Pain relief

\begin{abstract}
Phalanx bone metastasis as the initial presenting sign of lung cancer is a rare presentation. Lung cancer is known to metastasize to the bone, but rarely to the fingers. A 61-year-old male smoker presented with pain in the left ring finger. Severe pain discouraged the patient from using his left hand. An X-ray of the left hand showed a lytic bone lesion. The patient was treated with finger radiotherapy. Analgesics were no longer needed and the patient was able to reuse his left hand in his everyday life. Palliative radiotherapy relieved our patient and improved his quality of life.

(c) 2014 S. Karger AG, Basel
\end{abstract}

\section{Introduction}

Bone metastases most commonly affect the axial skeleton. Metastases to the hands are rarely observed. They comprise only $0.1 \%$ of all osseous metastases [1]. Only $7 \%$ of them affect the proximal phalanx [2].

Here we report a case of metastasis to the proximal phalanx of the left hand as the initial manifestation of a lung adenocarcinoma. Radiotherapy of the finger has been used to obtain pain relief and metastasis reduction. 
Sumodhee et al.: Radiotherapy for a Phalanx Bone Metastasis of a Lung Adenocarcinoma

\section{Case Report}

A 61-year-old male smoker presented in December 2013 at the CHU Sud Réunion with pain in his left ring finger and in the ribs, both secondary to indirect trauma a few weeks ago. Severe pain discouraged the patient from using his left hand in daily activities. He had no other complaints and was in good general condition. On physical examination of the hand, the left ring finger was edematous at the proximal interphalangeal joint (fig. 1). The finger movement was restricted. His left ring finger measured $80 \mathrm{~mm}$ in circumference, while the contralateral healthy finger had a circumference of $55 \mathrm{~mm}$.

We performed an X-ray of the rib cage, which showed a lytic lesion of the eighth rib. An $\mathrm{X}$-ray of the left hand showed a lytic bone lesion with the destruction of the bone cortex in the proximal phalanx and a swelling of the surrounding soft tissue (fig. 2). A CT scan of the chest showed several suspicious opacities, one in the left lung hilum, a stellar image at the apex of the right lung, and a lytic lesion of the anterior arc of the eighth rib (fig. 3). The pneumologist performed a bronchoscopy, but the first biopsies were negative. Then a biopsy of the rib mass identified an infiltration of the parietal pleura and striated muscle tissue by a pulmonary adenocarcinoma, moderately differentiated TTF1+, KRAS mutant, BRAF wild type, EGFR wild type, and with no ALK rearrangement. The bone scintigraphy showed multiple bone metastases on the rib cage, the spine, and the left scapula. The patient's left ring finger was very painful. He was given a nonsteroidal analgesic. The pain was morphine resistant. The patient received radiotherapy for his left ring finger in March 2014 (dose of total $30 \mathrm{~Gy} / 10$ fractions, 5 fractions/week, 6-MV X-rays with 5-mm bolus). Over the next month, the left ring finger became much less painful. Analgesics were no longer needed. The patient was able to use his left hand again in everyday life. The edema decreased (fig. 4), and the finger measured $75 \mathrm{~mm}$ in circumference. An X-ray of the left hand done 1 month after the end of the radiotherapy showed a decrease of the soft tissue swelling and an early reossification of the proximal phalanx (fig. 5). Chemotherapy with cisplatin, pemetrexed and bevacizumab was started at the end of the radiotherapy.

The patient is still alive at the time of this report.

\section{Discussion}

Digital metastases are very rare. The first description of bone metastases to the hand was reported in a case of breast cancer by Handley in 1906 [3].

The most common primary cancer site is the lung (44\%) [2]. Peripheral bone metastases are mostly associated with disseminated disease, but in our case, it was the initial manifestation of a lung adenocarcinoma. The clinical manifestation is usually pain, redness and edema [4]. It can be easily confused with an infection; an X-ray can be very helpful. Pathology may be necessary in case of doubt and additional exams such as chest CT and bronchoscopy should be performed to identify the primary lesion [5]. Bone scintigraphy is a good exam to identify other bone lesions.

Considering the rarity of cases, no standard management exists [6]. In reported cases, patients mostly have to be treated with an amputation of the finger [7-11]. Patients with bone metastases have a median survival of only 6 months [12], and a choice of treatment should be made considering this poor prognosis: palliative radiotherapy and non-steroidal analgesics helped our patient and improved his quality of life. 


\section{Case Reports in Oncology}

\begin{tabular}{l|l}
\hline Case Rep Oncol 2014;7:727-731 & \\
\hline DOI: 10.1159/000368345 & $\begin{array}{l}\text { ○ 2014 S. Karger AG, Basel } \\
\text { www.karger.com/cro }\end{array}$ \\
\hline
\end{tabular}

Sumodhee et al.: Radiotherapy for a Phalanx Bone Metastasis of a Lung Adenocarcinoma

\section{Disclosure Statement}

The authors declare no conflicts of interest.

\section{References}

1 Kerin R: The hand in metastatic disease. J Hand Surg (Am) 1987;2:77-83.

2 Flynn CJ, Danjoux C, Wong J, Christakis M, Rubenstein J, Yee A, et al: Two cases of acrometastasis to the hands and review of the literature. Curr Oncol 2008;15:51-58.

3 Handley WS: Cancer of the Breast and Its Operative Treatment, ed 2. London, John Murray, 1906.

4 Akjouj S, El Kettani N, Semlali S, et al: Thumb acrometastasis revealing lung adenocarcinoma: a case report with review of literature. Chir Main 2006;25:106-108.

5 Jakhar SL, Dana R, Punia DP: Cancer lung: an unusual presentation. Indian J Med Paediatr Oncol 2009;30:149-150.

6 Madjidi A, Cole P, Laucirica R: Digital acrometastasis: a rare initial sign of occult pulmonary squamous cell carcinoma. J Plast Reconstr Aesthet Surg 2009;62:e365-e367.

7 Lookingbill DP, Spangler N, Sexton FM: Skin involvement as the presenting sign of internal carcinoma: a retrospective study of 7,316 cancer patients. J Am Acad Dermatol 1990;22:19-26.

8 Cohen PR: Cutaneous manifestations of internal malignancy; in Callen JP, Bone RC (eds): Current Practice of Medicine, vol 2. Philadelphia, Current Medicine, 1996, pp 19.1-19.13.

9 Vanhooteghem 0, Dumont M, Andre J, et al: Bilateral subungual metastasis from squamous cell carcinoma of the lung: a diagnostic trap (in French). Rev Med Liege 1999;54:653-654.

-10 Hagar CM, Cohen PR: Cutaneous lesions of visceral malignancy mimicking pyogenic granuloma. Cancer Invest 1999;17:385-390.

11 Rinonapoli G, Caraffa A, Antenucci R: Lung cancer presenting as a metastasis to the carpal bones: a case report. J Med Case Rep 2012;6:384.

12 Keramidas E, Brotherston M: Extensive metastasis to the hand from undiagnosed adenocarcinoma of the lung. Scand J Plast Reconstr Surg Hand Surg 2005;39:113-115.
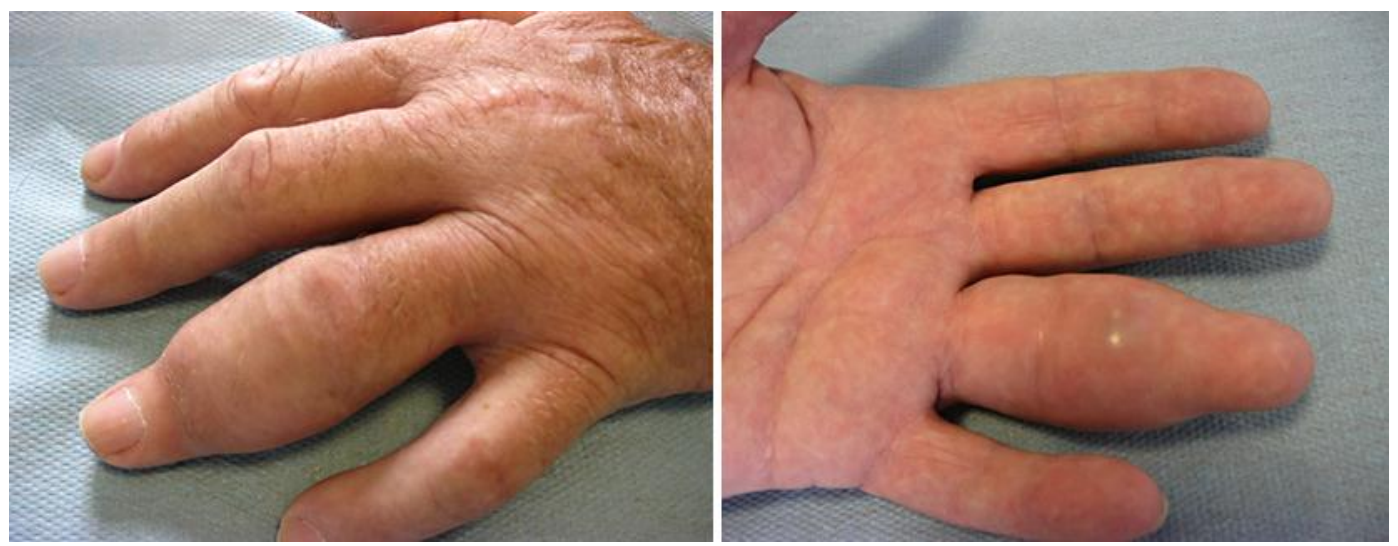

Fig. 1. Left ring finger lesion. 


\section{Case Reports in Oncology}

\begin{tabular}{l|l}
\hline Case Rep Oncol 2014;7:727-731 & \\
\hline DOI: $10.1159 / 000368345$ & $\begin{array}{l}\text { C 2014 S. Karger AG, Basel } \\
\text { www.karger.com/cro }\end{array}$ \\
\hline
\end{tabular}

Sumodhee et al.: Radiotherapy for a Phalanx Bone Metastasis of a Lung Adenocarcinoma
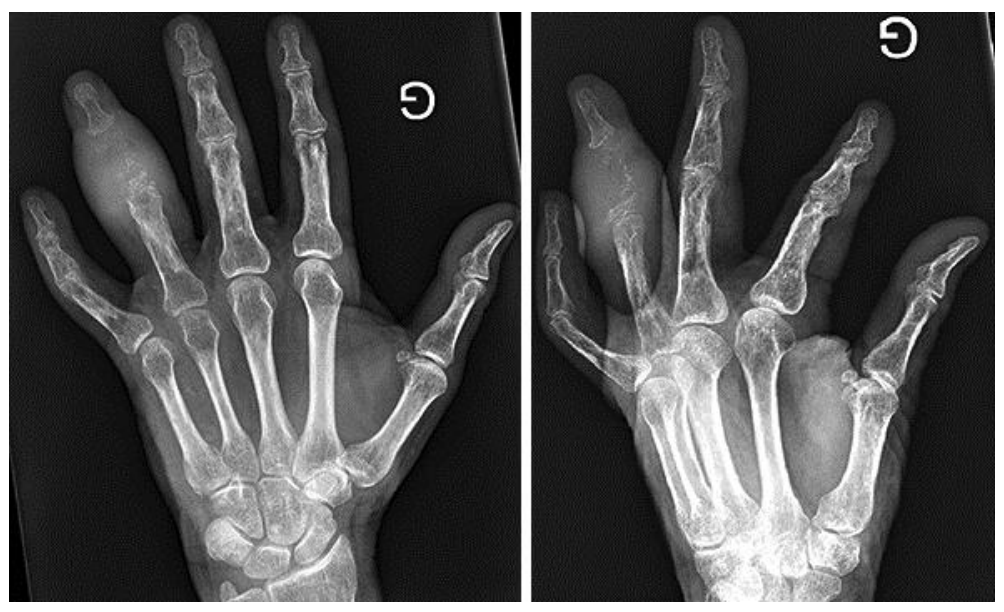

Fig. 2. X-ray showing a lytic bone lesion with the destruction of the bone cortex in the proximal phalanx and swelling of the surrounding soft tissue.
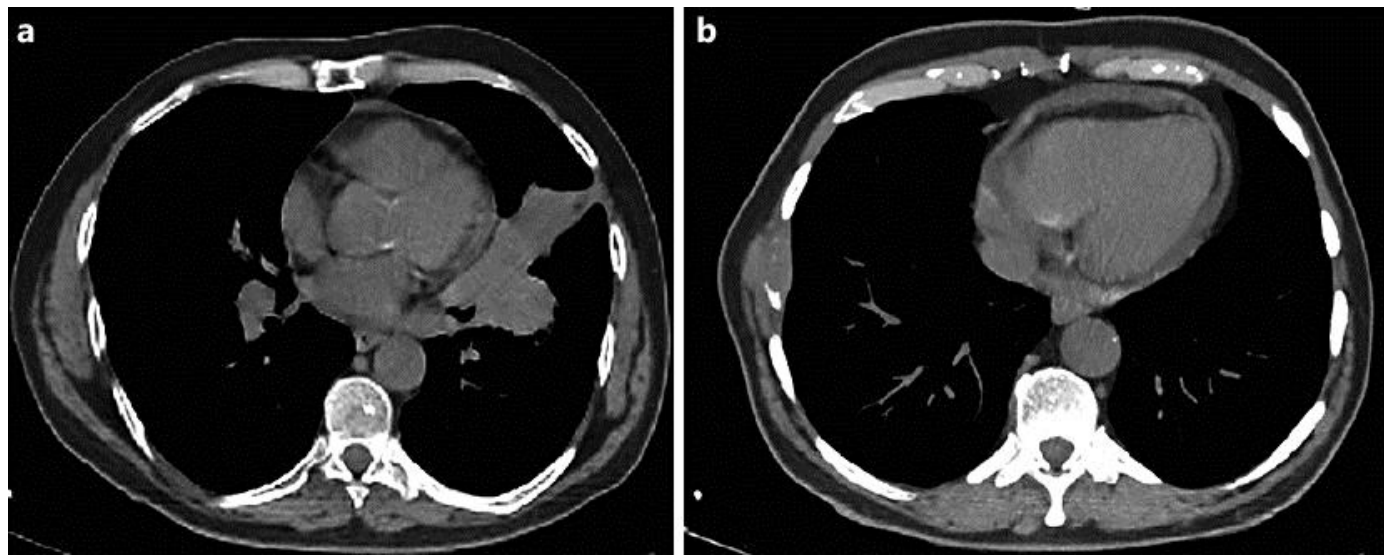

Fig. 3. a Chest CT scan showing opacity in the left lung hilum. b Chest CT scan showing a lytic lesion of the anterior arc of the eighth rib.


Fig. 4. Left ring finger lesion after radiation therapy. 


\section{Case Reports in Oncology}

\begin{tabular}{l|l}
\hline Case Rep Oncol 2014;7:727-731 & \multicolumn{2}{l}{} \\
\hline DOI: $10.1159 / 000368345$ & $\begin{array}{l}\text { C 2014 S. Karger AG, Basel } \\
\text { www.karger.com/cro }\end{array}$ \\
\hline
\end{tabular}

Sumodhee et al.: Radiotherapy for a Phalanx Bone Metastasis of a Lung Adenocarcinoma
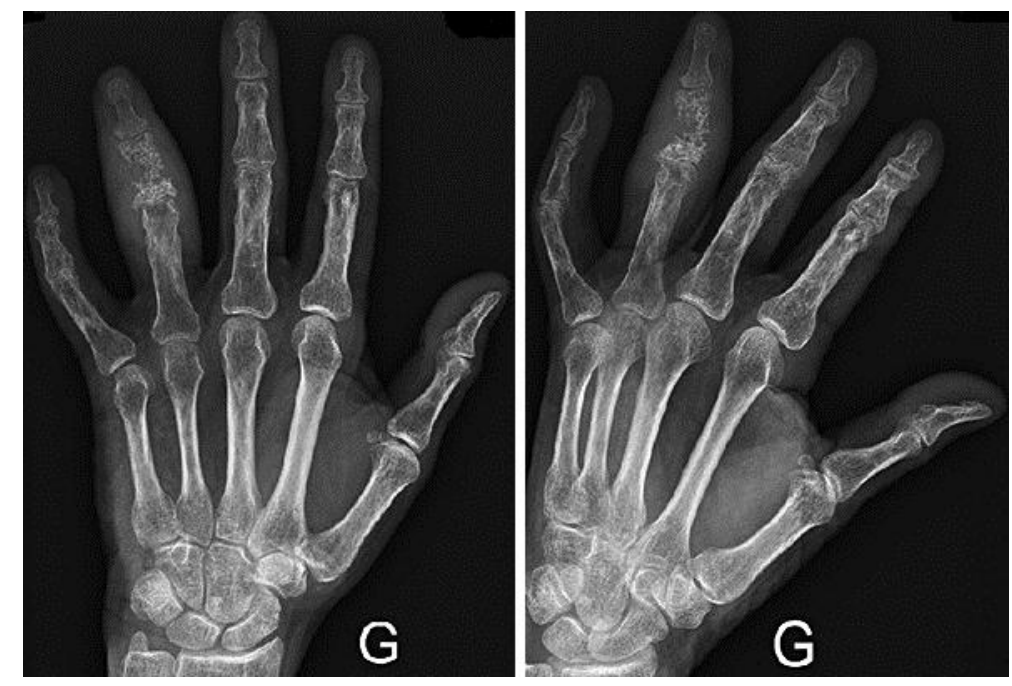

Fig. 5. X-ray of the left hand after radiation therapy showing a decrease of the soft tissue swelling and an early reossification of the proximal phalanx. 